\title{
KEMAMPUAN PEMAHAMAN KONSEP MATEMATIKA SISWA DITINJAU DARI MINAT BELAJAR DAN GENDER
}

\author{
Rahmat Winata*1, Rizki Nurhana Friantini ${ }^{2}$ \\ ${ }^{1,2}$ Program Studi Pendidikan Matematika, STKIP Pamane Talino \\ *gublik.tata@gmail.com
}

\begin{abstract}
ABSTRAK
Penelitian ini bertujuan untuk menganalisis kemampuan pemahaman konsep matematika siswa kelas X IIS SMA Negeri 1 Jelimpo tahun ajaran 2018/2019 ditinjau dari Minat Belajar dan Gender. Jenis penelitian ini adalah penelitian kualitatif. Pemilihan subjek dengan purposive sampling. Pengumpulan data dengan metode tes dan wawancara. Validitas data menggunakan triangulasi metode. Hasil penelitian adalah siswa laki-laki dan perempuan dengan minat belajar tinggi mempunyai kemampuan pemahaman konsep yaitu mampu menjelaskan, menerapkan hubungan antara konsep dan prosedur, dan memberikan contoh dan bukan contoh tetapi tidak mampu mengembangkan konsep. Siswa laki-laki dengan minat belajar sedang yaitu mampu menjelaskan dan memberikan contoh dan bukan contoh, tetapi kurang mampu menerapkan hubungan antara konsep dan prosedur serta tidak mampu mengembangkan konsep. Siswa perempuan dengan minat belajar sedang mampu menjelaskan, menerapkan hubungan antara konsep dan prosedur, dan memberikan contoh dan bukan contoh tetapi tidak mampu mengembangkan konsep. Siswa laki-laki dengan minat belajar rendah mampu menerapkan hubungan antara konsep dan prosedur dan memberikan contoh dan bukan contoh tetapi tidak mampu menjelaskan dan mengembangkan konsep. Siswa perempuan dengan minat belajar rendah tidak mampu menjelaskan, tidak mampu menerapkan hubungan antara konsep dan prosedur, tidak mampu memberikan contoh dan bukan contoh, dan tidak mampu mengembangkan konsep yang telah dipelajari.
\end{abstract}

Kata kunci: pemahaman konsep matematika, minat belajar, gender.

\begin{abstract}
This study aims to analyze the conceptual understanding ability's students of class X IIS SMA 1 Jelimpo 2018/2019 academic year in term of learning interests and gander. This type of research is a qualitative research. The subject selection used purposive sampling. The data collection used test and interview methods. The validity of the data used triangulation method. The results of this study show that male and female students who have high learning interest have the ability to understand the concept that being able to explain, to apply the relationship between concepts and procedures, and provide examples and not examples, but they are unable to develop concepts. Male students who have medium learning interest are able to explain and give examples and not examples, but are less able to apply the relationship between concepts and procedures and also unable to develop concepts. Female students who have medium learning interest are able to explain, to apply relationship between concepts and procedures, and to provide examples and not examples, but they are unable to explain and to develop concepts. Male students who have low learning interest are able to apply the relationship between concepts and procedures and to provide examples and not examples, but they are unable to explain and to develop concepts. Female students who have a low interest learning are unable to explain, unable to apply the relationship between concepts and procedures, unable to provide examples and not examples, and unable to develop concepts that have been learned.
\end{abstract}

Key words: mathematics concept understanding, learning interest, gender.

\section{Pendahuluan}

Matematika merupakan salah satu mata pelajaran yang penting dan perlu untuk dikuasai oleh siswa. Matematika penting karena dekat dengan kehidupan kita dan bermanfaat pada kehidupan sehari-hari. Dari mulai berhitung, operasi bilangan, untung dan rugi pada aritmatika sosial, maupun pengolahan dan penyajian data pada statistika, semua itu diterapkan 
dan sering kita jumpai pada kehidupan kita. Oleh karena itu sudah seharusnya mata pelajaran matematika pada pembelajaran di sekolah dikuasai oleh siswa.

Salah satu objek pada matematika adalah konsep. Konsep yaitu suatu kategori, perangkat, atau kelas yang memiliki kesamaan karakteristik (Eggen \& Kauchak, 2012). Konsep perlu untuk memperoleh dan mengkomunikasikan pengetahuan (Nasution, 2011). Dengan menguasai konsep-konsep kemungkinan untuk memperoleh pengetahuan baru tidak terbatas. Tanpa konsep belajar akan sangat terhambat. Hanya dengan bantuan konsep dapat dijalankan pendidikan formal.

Pembelajaran matematika di sekolah, dimulai dari yang paling mudah sampai paling sulit, dari yang konkrit sampai yang abstrak. Belajar matematika harus bertahap, berurutan, dan berkelanjutan. Konsep pada matematika disusun secara sistematis, logis, dan hierarkis dari yang mudah sampai yang komplek, memahami konsep matematika adalah dasar dari pembelajaran matematika (Ilyas \& Basir, 2016). Oleh karena itu pengalaman belajar yang dahulu merupakan dasar untuk belajar selanjutnya. Terkadang siswa mengalami kesulitan pada suatu konsep tetapi tidak segera mengatasinya. Hal ini dapat membuat konsep-konsep selanjutnya juga menjadi tidak dikuasai. Oleh karena itu pemahaman konsep merupakan kemampuan yang penting untuk dikuasai oleh siswa.

Pemahaman diartikan dari kata understanding. Dalam KBBI, pemahaman diartikan sebagai kesanggupan intelegensi untuk menangkap situasi atau perbuatan. Pemahaman adalah salah satu dimensi kognitif pada taksonomi Bloom. Siswa memahami ketika mereka menghubungkan pengetahuan "baru" dan pengetahuan lama mereka (Anderson \& Krathwohl, 2010). Lebih tepatnya pengetahuan yang baru masuk dipadukan dengan skema dan kerangka kognitif yang telah ada. Kemampuan pemahaman matematis adalah kemampuan menyerap dan memahami ide-ide matematika (Lestari \& Yudhanegara, 2017).

Pemahaman konsep merupakan salah satu standar kecakapan yang harus dikuasai oleh siswa pada pembelajaran matematika. Menurut Kilpatrick (Lestari \& Yudhanegara, 2017) pemahaman konsep merupakan kemampuan yang berkenaan dengan memahami ide-ide matematika yang menyeluruh dan fungsional. Pemahaman konsep adalah pemahaman dalam pembelajaran yaitu tingkat kemampuan yang mengharapkan seseorang mampu memahami arti atau konsep, situasi, dan fakta yang diketahuinya (Rifa'i \& Dahliyah, 2018). Pemahaman konsep matematika merupakan kemampuan bersikap, berpikir, dan bertindak yang ditunjukkan oleh siswa dalam memahami definisi, pengertian, ciri khusus, hakikat, dan inti /isi dari materi matematika dan kemampuan dalam memilih, serta menggunakan prosedur secara efisien dan tepat (Maulida, Mardiyana, \& Pramudya, 2017).

Pemahaman konsep penting pada pembelajaran matematika. Disampaikan oleh Zulkardi (Ilyas \& Basir, 2016) bahwa siswa harus memahami konsep matematika lebih lanjut apabila ingin memecahkan masalah dan menerapkan pembelajaran di dunia nyata. Pemahaman konsep sangat penting, dengan menguasai konsep membantu siswa dalam belajar matematika (Ilyas \& Basir, 2016). Bila anak memahami suatu konsep maka ia akan dapat menggeneralisasikannya dalam berbagai situasi lainnya yang tidak digunakan dalam situasi belajar (Nasution, 2011). Selanjutnya indikator pemahaman konsep adalah 1) Mampu menjelaskan tentang apa yang telah dicapai, 2) Mampu menerapkan hubungan antara konsep dan prosedur, 3) Mampu memberikan contoh dan bukan contoh dari konsep yang sedang dipelajari. 4) Mampu mengembangkan konsep yang telah dipelajari (Ilyas \& Basir, 2016). 
Hasil observasi pendahuluan mengenai pemahaman konsep siswa kelas X IIS SMA Negeri 1 Jelimpo tahun ajaran 2018/2019 pada pokok materi Sistem Persamaan dan Pertidaksamaan Linear diperoleh kesimpulan bahwa siswa belum dapat menjelaskan mengenai persamaan dan pertidaksamaan dengan benar. Selain itu siswa belum dapat memberikan contoh dengan tepat mengenai persamaan dan pertidaksamaan. Oleh karena itu diketahui bahwa pemahaman konsep masih menjadi salah satu permasalahan yang terjadi pada pembelajaran matematika. Dikarenakan banyaknya konsep yang harus dipahami siswa membuat siswa menjadi malas untuk mempelajari dan memahaminya. Apabila masalah tersebut dibiarkan akan membuat kesulitan siswa dalam memahami konsep matematika menjadi berlarut-larut sehingga semakin banyak konsep matematika yang tidak dikuasai siswa.

Kemampuan pemahaman matematika yang merupakan aspek kognitif siswa dipengaruhi oleh banyak faktor baik dari dalam maupun luar diri siswa tersebut. Salah satu faktor dari dalam diri siswa yang dapat mempengaruhi kemampuan pemahaman konsep adalah minat belajar siswa. Slameto (Friantini \& Winata, 2019) menyatakan minat adalah suatu rasa lebih suka dan rasa keterikatan pada suatu hal atau aktivitas, tanpa ada yang menyuruh. Minat belajar siswa merupakan rasa ketertarikan siswa terhadap belajar di mana siswa tersebut ingin mendalami, maupun melakukan sehingga terjadi perubahan pada diri siswa tersebut (Sari \& Harini, 2015). Selanjutnya Guilford (Lestari \& Yudhanegara, 2017) menyatakan minat belajar adalah dorongan-dorongan dari dalam diri siswa secara psikis dalam mempelajari sesuatu dengan penuh kesadaran. Minat belajar yang tinggi akan memberikan pengaruh yang tinggi pula terhadap pemahaman siswa. Begitu juga dengan siswa yang memiliki minat belajar yang sedang dan rendah, akan berpengaruh dengan pemahaman siswa. Apabila siswa tidak memiliki minat untuk belajar, maka siswa akan sulit memahami materi (Komariyah, Afifah, \& Resbiantoro, 2018).

Faktor yang lain yang mempengaruhi kemampuan pemahaman konsep adalah gender. Gender merupakan istilah untuk menjelaskan perbedaan laki-laki dan perempuan yang mempunyai sifat bawaan (ciptaan Tuhan) dan bentukan budaya (konstruksi sosial) termasuk perbedaan dalam memecahkan masalah (Sudia, 2015). Laki-laki dan perempuan memang terlihat beda dan memiliki organ-organ serta hormon-hormon seks yang berbeda, dan oleh sebab itu ada anggapan bahwa laki-laki dan perempuan tentunya juga berbeda dalam cara mereka berpikir, bertindak dan merasakan sesuatu. Anak laki-laki sedikit lebih baik dibandingan perempuan dalam matematika dan sains. Secara umum siswa laki-laki sama dengan siswa perempuan, akan tetapi siswa laki-laki mempunyai daya abstraksi yang lebih baik daripada siswa perempuan sehingga memungkinkan siswa laki-laki lebih baik daripada siswa perempuan dalam bidang matematika, karena pada umumnya matematika berkenaan dengan pengertian yang abstrak (Santrock, 2007).

Berdasarkan penjelasan di atas, maka tujuan penelitian ini yaitu untuk mengetahui kemampuan pemahaman konsep siswa kelas X IIS SMA Negeri 1 Jelimpo tahun ajaran 2018/2019 berjenis kelamin laki-laki dan perempuan yang mempunyai minat belajar tinggi, sedang, dan rendah. Pada penelitian ini diperoleh hasil mengenai deskripsi kemampuan pemahaman konsep siswa kelas X IIS SMA Negeri 1 Jelimpo tahun ajaran 2018/2019 untuk siswa berjenis kelamin laki-laki dan perempuan yang mempunyai minat belajar tinggi, siswa berjenis kelamin laki-laki dan perempuan yang mempunyai minat belajar sedang, serta siswa berjenis kelamin laki-laki dan perempuan yang mempunyai minat belajar rendah. 


\section{Metode Penelitian}

Jenis penelitian ini adalah kualitatif. Bogdan dan Taylor (Moleong, 2012), menyatakan penelitian kualitatif merupakan prosedur penelitian yang menghasilkan data deskriptif berupa kata-kata tertulis atau lisan dari orang-orang dan perilaku yang dapat diamati. Dapat disimpulkan bahwa penelitian ini merupakan penelitian kualitatif yang menghasilkan data deskriptif berupa kata-kata tertulis atau lisan dari subjek yang berupa data pemahaman konsep siswa kelas X IIS SMA Negeri 1 Jelimpo tahun ajaran 2018/2019 yang mempunyai minat belajar tinggi, sedang, dan rendah dan berjenis kelami laki-laki ataupun perempuan.

Siswa kelas X IIS SMA Negeri 1 Jelimpo sebanyak 76 siswa, dengan siswa laki-laki sebanyak 43 siswa dan siswa perempuan sebanyak 33 siswa. Subjek dalam penelitian ini sebanyak 6 siswa kelas X IIS SMA Negeri 1 Jelimpo tahun ajaran 2018/2019, yaitu dua siswa berjenis kelamin laki-laki dan perempuan untuk setiap tingkatan minat belajar. Penentuan subjek dengan menggunakan purposive sampling. Sampling purposive adalah teknik penentuan sampel dengan pertimbangan tertentu (Sugiyono, 2010). Pertimbangan yang dimaksudkan pada penelitian ini adalah siswa dipilih berdasarkan minat belajar dan gender selain itu dari kebenaran dan kelengkapan jawaban siswa sehingga diperoleh data kemampuan pemahaman konsep yang maksimal. Sedangkan untuk pengelompokkan siswa berdasarkan minat belajar yaitu siswa yang mempunyai minat belajar tinggi, sedang, dan rendah berdasarkan kategori pada Tabel 1 berikut.

Tabel 1 Kategori Pengelompokkan Minat Belajar Siswa

\begin{tabular}{cl}
\hline Skor & \multicolumn{1}{c}{ Kategori } \\
\hline$X>\overline{\boldsymbol{X}}+0,5 s$ & Minat belajar tinggi \\
$\overline{\boldsymbol{X}}-0,5 s \leq \mathrm{X} \leq \overline{\boldsymbol{X}}+0,5 s$ & Minat belajar sedang \\
$X<\overline{\boldsymbol{X}}-0,5 s$ & Minat belajar rendah \\
\hline
\end{tabular}

Keterangan:

$X$ : nilai angket masing-masing siswa di kelas tersebut

$\overline{\boldsymbol{X}}$ : rerata nilai angket masing-masing siswa di kelas tersebut $s:$ standar deviasi

Pada penelitian ini, data yang dibutuhkan dikumpulkan sendiri oleh peneliti sehingga peneliti merupakan instrumen utama dalam penelitian. Selanjutnya peneliti menggunakan instrumen bantu berupa angket minat belajar, tes pemahaman konsep dan pedoman wawancara.

Dalam penelitian kualitatif pemeriksaan keabsahan data dapat dilakukan dengan beberapa teknik. Teknik pemeriksaan keabsahan data pada penelitian ini adalah dengan triangulasi. Triangulasi adalah teknik pemeriksaan keabsahan data yang memanfaatkan sesuatu yang lain di luar data itu untuk keperluan pengecekan atau sebagai pembanding terhadap data itu (Moleong, 2012). Pada penelitian ini, triangulasi yang digunakan adalah triangulasi metode. Menurut Patton (Moleong, 2012) triangulasi metode yaitu pengecekan derajat kepercayaan penemuan hasil penelitian beberapa teknik pengumpulan data. Pada penelitian ini, proses triangulasi data yang dilakukan, yaitu peneliti menganalisis berdasarkan data tes pemahaman konsep dibandingkan dengan data kegiatan wawancara untuk masing-masing subjek yang mempunyai minat belajar tinggi, sedang, dan rendah masing-masing untuk siswa laki-laki dan perempuan hingga diperoleh data yang jenuh atau sama.

4 \begin{tabular}{l|l} 
C2020 by Department of Mathematics Education, UMP, Purwokerto, Indonesia \\
p-ISSN 2477-409X, e-ISSN: 2549-9084 and website: http://jurnal nasional.ump.ac.id/index.php/alphamath/
\end{tabular} 


\section{Hasil dan Pembahasan}

Dari hasil angket minat belajar diperoleh siswa yang mempunyai minat belajar tinggi sebanyak 25 siswa, siswa yang mempunyai minat belajar sedang sebanyak 28 siswa dan siswa yang mempunyai minat belajar rendah sebanyak 23 siswa. Kemudian dari masing-masing tingkatan minat belajar dipilih dua siswa yang memberikan jawaban yang paling lengkap dari hasil tes pemahaman konsep untuk diwawancara agar diperoleh data yang valid untuk selanjutnya data tersebut dianalisis.

Berdasarkan hasil tes dan wawancara yang dilakukan pada subjek untuk masing-masing tingkat minat belajar dan gender diperoleh data pemahaman konsep siswa pada pokok materi Persamaan dan Pertidaksamaan Linear. Data untuk masing-masing subjek dikategorikan menjadi 4 indikator pemahaman konsep. Berikut hasil analisis tentang pemahaman konsep untuk siswa dengan masing-masing tingkat minat belajar yang berjenis kelamin laki-laki dan perempuan.

Minat tinggi : Jenis kelamin laki-laki

Untuk indikator pertama yaitu mampu menjelaskan tentang apa yang telah dicapai, subjek TL mampu menjelaskan mengenai sistem persamaan linear dua variabel (SPLDV) dan sistem persamaan linear tiga variabel (SPLTV) dengan menyebutkan ciri-ciri dari masing-masing sistem. Berikut jawaban subjek TL untuk indikator pertama.

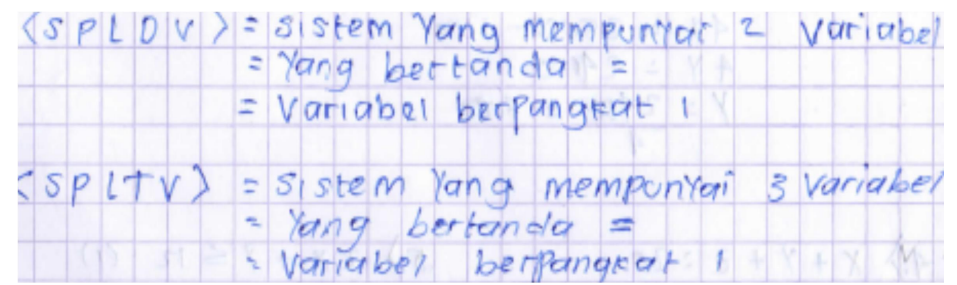

Gambar 1 Jawaban subjek TL untuk indikator pemahaman konsep pertama

Dari jawaban di atas (Gambar 1) dapat dilihat bahwa subjek TL menjelaskan SPLDV sebagai sistem yang mempunyai dua variabel, yang bertanda sama dengan $(=)$ dan variabel berpangkat 1. Sedangkan SPLTV dijelaskan sebagai sistem yang mempunyai tiga variabel, yang bertanda sama dengan (=) dan variabel berpangkat 1. Pada saat wawancara, subjek menjelaskan SPLDV dan SPLTV dengan jawaban yang sama.

Untuk indikator kedua yaitu mampu menerapkan hubungan antara konsep dan prosedur, subjek TL mampu menerapkan hubungan antara penyelesaian SPLDV dengan menggunakan prosedur eliminasi dan subtitusi. Berikut jawaban subjek TL untuk indikator kedua. 


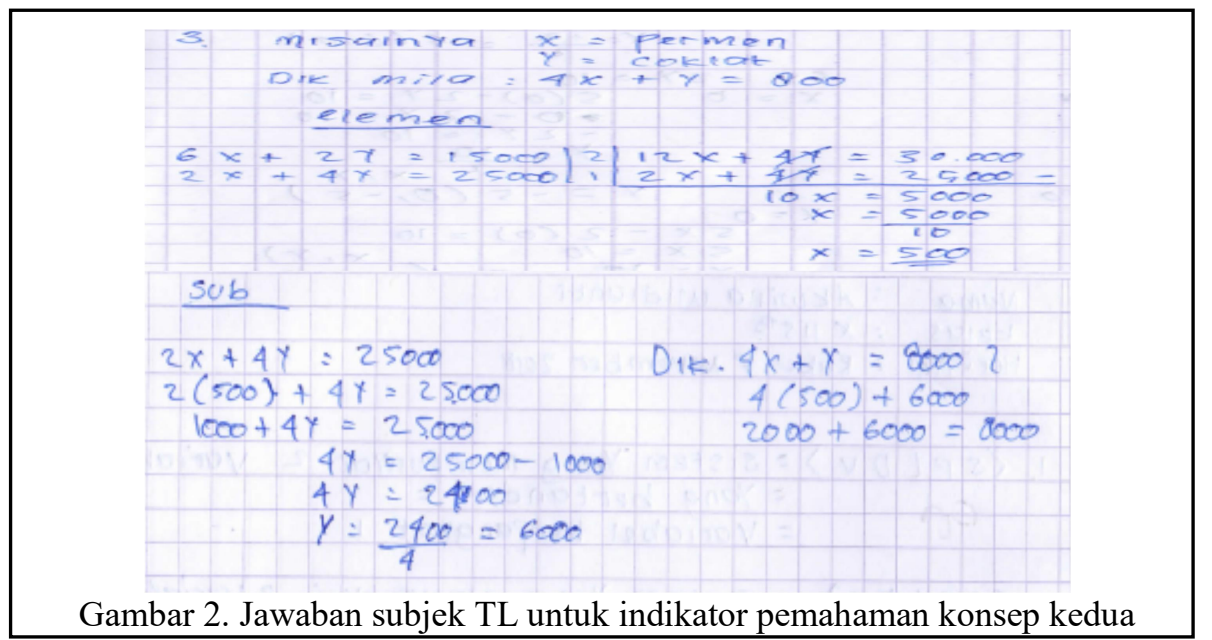

Dari jawaban di atas (gambar 2) dapat dilihat bahwa pada awal langkah penyelesaian subjek memisalkan permen dengan variabel $x$ dan cokelat dengan variabel $y$ untuk selanjutnya mencari harga yang harus dibayar bila membeli 4 permen dan satu cokelat yang dimisalkan dengan $4 x+y$. Selanjutnya subjek melakukan proses eliminasi yaitu dengan mengeliminasi variabel $y$ sehingga diperoleh nilai dari variabel $x$ yaitu $x=500$. Kemudian subjek mencari nilai dari variabel $y$ dengan cara mensubtitusikan nilai $x$ ke persamaan dua yaitu $2 x+4 y=$ 25000. Setelah dihitung diperoleh nilai dari variabel $y$, yaitu $y=6000$. Setelah diperoleh nilai $x$ dan $y$, subjek mensubtitusikan nilai tersebut ke persamaan yang ingin dicari hasilnya dan diperoleh harga yang harus dibayar adalah 8000 . Proses dan hasil perhitungan yang diperoleh subjek benar. Pada kegiatan wawancara, subjek juga dapat menjelaskan dengan baik mengenai proses penyelesaian yang dilakukannya pada soal ini. Dapat disimpulkan bahwa subjek dapat menerapkan hubungan antara konsep penyelesaian SPLDV dengan prosedur campuran yaitu eliminasi dan subtitusi.

Untuk indikator ketiga yaitu mampu memberikan contoh dan bukan contoh dari konsep yang sedang dipelajari, subjek TL mampu memberikan contoh dari SPLDV dan SPLTV dengan benar. Berikut jawaban subjek TL untuk indikator ketiga.

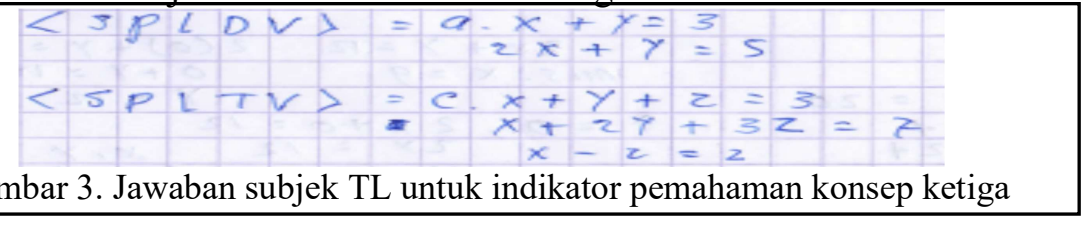

Dari jawaban subjek (Gambar 3), dapat dilihat bahwa memilih dengan benar sistem persamaan yang merupakan SPLDV dan SPLTV, yaitu untuk SPLDV subjek menuliskan jawaban $\left\{\begin{array}{c}x+y=3 \\ 2 x+y=5\end{array}\right.$, sedangkan untuk SPLTV subjek menuliskan jawaban $\left\{\begin{array}{c}x+y+z=3 \\ x+2 y+3 z=7 \text {. Dari hasil wawancara subjek juga memberikan jawaban yang sama untuk } \\ x-z=2\end{array}\right.$ SPLDV dan SPLTV. Dapat disimpulkan bahwa subjek mampu memberikan contoh dan bukan contoh dari konsep yang dipelajari yaitu mengenai SPLDV dan SPLTV.

Untuk indikator keempat yaitu mampu mengembangkan konsep yang telah dipelajari, subjek TL tidak mampu mengembangkan konsep mengenai daerah penyelesaian dari suatu pertidaksamaan. Berikut jawaban subjek TL untuk indikator keempat. 


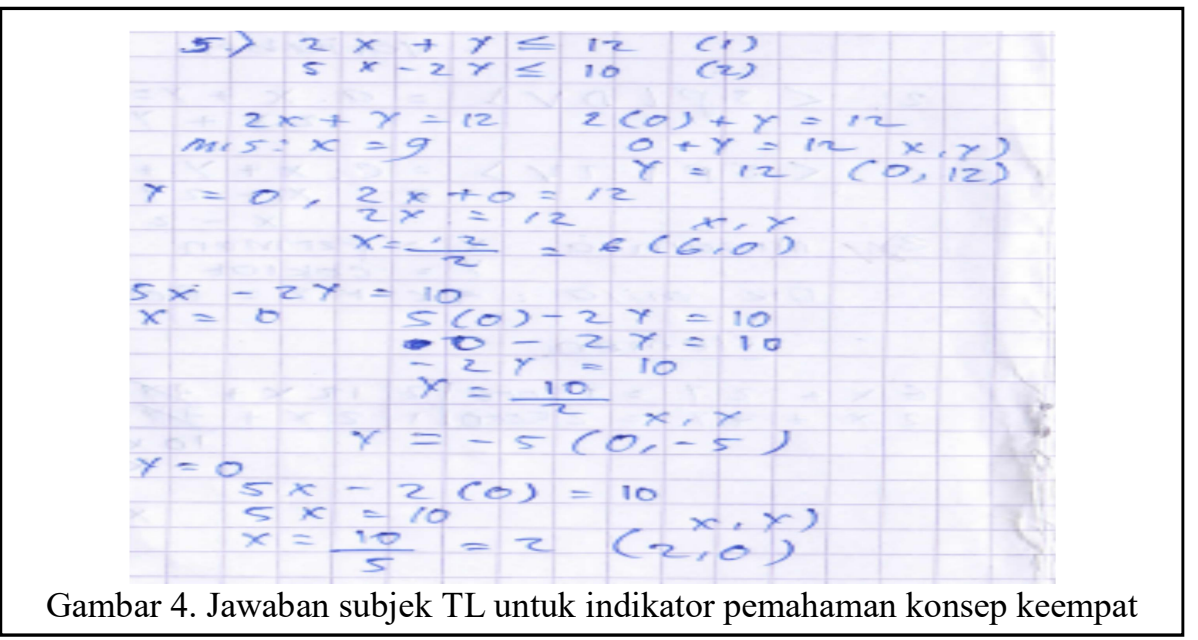

Dari jawaban subjek di atas (Gambar 4), dapat dilihat bahwa subjek tidak dapat mencari hasil dari suatu pertidaksamaan sehingga menggantinya menjadi persamaan. Dan untuk menyelesaikan persamaan tersebut subjek mensubtitusi nilai variabel $x$ dan $y$. Untuk pertidaksamaan pertama yaitu $2 x+y \leq 12$ diubah menjadi $2 x+y=12$, selanjutnya subjek mengganti nilai $x$ menjadi $x=0$ dan diperoleh nilai $y=12$. Kemudian menggantikan nilai $y$ menjadi $y=0$ sehingga diperoleh nilai $x=6$. Dari langkah tersebut diperoleh titik penyelesaian yaitu $(0,12)$ dan $(6,0)$. Begitu juga dengan pertidaksamaan kedua, subjek menyelesaikannya dengan cara yang sama. hal ini menunjukkan subjek belum dapat menentukan daerah penyelesaian dari suatu pertidaksamaan. Dari hasil wawancara diketahui bahwa subjek masih bingung mengenai konsep penyelesaian persamaan dan pertidaksamaan. Dapat disimpulkan bahwa subjek TL belum mampu mengembangkan konsep yang telah dipelajari yaitu berkaitan dengan daerah penyelesaian dari suatu pertidaksamaan.

\section{Minat tinggi: Jenis kelamin perempuan}

Untuk indikator pertama yaitu mampu menjelaskan tentang apa yang telah dicapai, subjek TP mampu menjelaskan mengenai SPLDV dan SPLTV cukup baik. berikut jawaban subjek untuk indikator pertama.

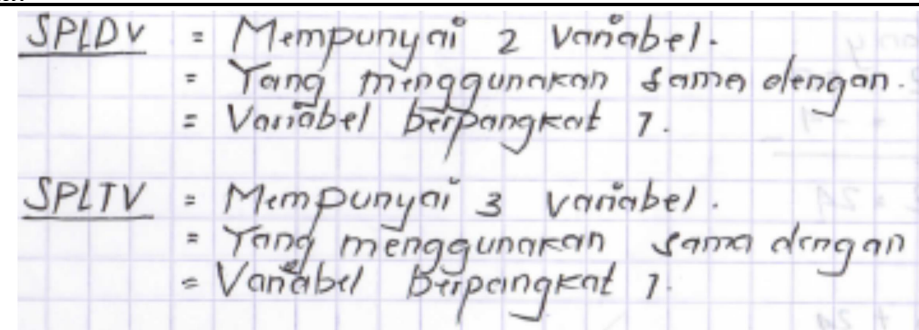

Gambar 5. Jawaban subjek TP untuk indikator pemahaman konsep pertama

Dari jawaban subjek di atas (Gambar 5) dapat dilihat bahwa subjek menjelaskan pengertian dari SPLDV dan SPLTV dengan menyebutkan ciri-ciri dari masing-masing sistem persamaan. Untuk SPLDV subjek menjelaskan yaitu mempunyai dua variabel, yang menggunakan sama dengan (=), dan variabel berpangkat 1. Sedangkan untuk SPLTV subjek menjelaskan dengan mempunyai 3 variabel, yang menggunakan sama dengan $(=)$, dan variabel berpangkat 1 . Ketika kegiatan wawancara, subjek TP menjelaskan dengan menambahkan kata persamaan pada penjelasannya yaitu SPLDV adalah persamaan yang mempunyai dua variabel, menggunakan sama dengan (=), dan variabelnya berpangkat 1 . Begitu juga dengan SPLTV 
adalah persamaan yang mempunyai tiga variabel, menggunakan sama dengan $(=)$, dan variabel berpangkat 1. Dapat disimpulkan subjek TP cukup mampu menjelaskan tentang apa yang telah dicapai yaitu penjelasan mengenai SPDV dan SPLTV.

Untuk indikator kedua yaitu mampu menerapkan hubungan antara konsep dan prosedur, subjek TP mampu menerapkan hubungan antara menentukan penyelesaian SPLDV dengan prosedur yang digunakan yaitu eliminasi dan subtitusi. Berikut jawaban subjek untuk indikator kedua.

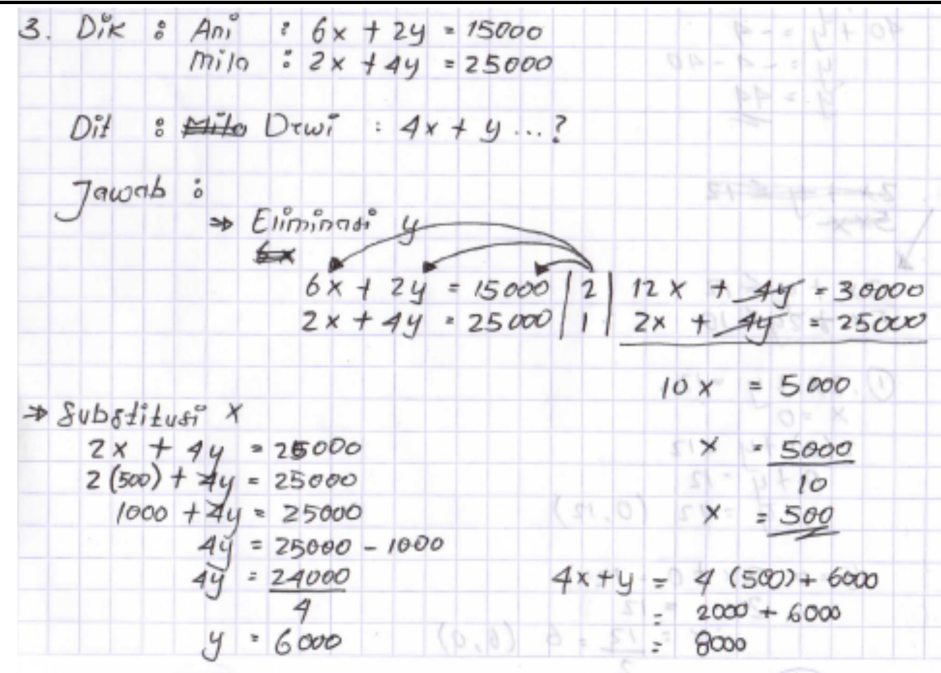

Gambar 6. Jawaban subjek TP untuk indikator pemahaman konsep kedua

Dari jawaban subjek di atas (Gambar 6) pada penyelesaian soal ini langkah pertama yang dilakukan subjek adalah menuliskan persamaan dari harga yang harus dibayar Ani yaitu $6 x+$ $2 y=15000$ dan harga yang harus dibayar Mila yaitu $2 x+4 y=25000$, selanjutnya ditanyakan harga yang harus dibayar Dewi yaitu $4 x+y$. Prosedur yang dilakukan subjek yaitu melakukan proses eliminasi variabel $y$ sehingga diperoleh nilai dari variabel $x$, yaitu $x=500$. Kemudian nilai variabel $x$ disubtitusikan ke persamaan dua (harga yang dibayar Mila) yaitu $2 x+4 y=$ 25000 sehingga diperoleh nilai variabel $y$, yaitu $y=6000$. Dari hasil variabel $x$ dan $y$ yang sudah diperoleh kemudian disubtitusikan pada persamaan yang ditanya yaitu $4 x+y$ sehingga diperoleh hasil 8000. Pada kegiatan wawancara, subjek juga dapat menjelaskan dengan jelas mengenai prosedur penyelesaian yang dilakukannya. Dapat disimpulkan bahwa subjek dapat menerapkan hubungan antara konsep penyelesaian SPLDV dengan prosedur yang digunakan adalah metode campuran yaitu metode eliminasi dan subtitusi.

Untuk indikator ketiga yaitu mampu memberikan contoh dan bukan contoh dari konsep yang sedang dipelajari, subjek TP dapat memberikan contoh dari SPLDV dan SPLTV dengan benar. Berikut jawaban subjek untuk indikator ketiga.

$$
\begin{aligned}
& S P L D V=C \\
& S P L T V=C
\end{aligned}
$$

Gambar 7. Jawaban subjek TP untuk indikator ketiga

Dari jawaban subjek di atas (Gambar 7), subjek menuliskan opsi jawaban a yaitu $\left\{\begin{array}{c}x+y=3 \\ 2 x+y=5\end{array}\right.$ sebagai contoh dari SPLDV dan opsi jawaban c yaitu $\left\{\begin{array}{c}x+y+z=3 \\ x+2 y+3 z=7 \text { sebagai contoh dari } \\ x-z=2\end{array}\right.$ SPLTV. Dari hasil wawancara juga diperoleh jawaban yang sama dari subjek TP. Dapat

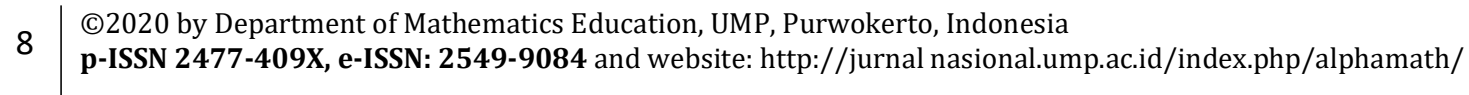


disimpulkan bahwa subjek TP mampu memberikan contoh dan bukan contoh dari konsep yang sedang dipelajari yaitu konsep SPLDV dan SPLTV.

Untuk indikator keempat yaitu mampu mengembangkan konsep yang telah dipelajari, subjek TP tidak mampu mengembangkan konsep yang dipelajari, khususnya menentukan daerah penyelesaian suatu pertidaksamaan. Berikut jawaban subjek untuk indikator keempat.

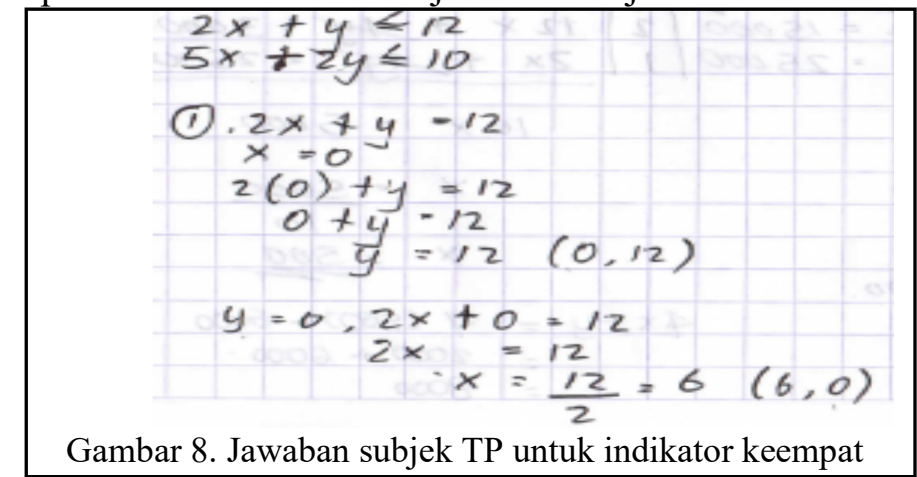

Dari jawaban subjek di atas (Gambar 8), dapat dilihat bahwa subjek mencari penyelesaian pertidaksamaan dengan mengubah bentuknya menjadi persamaan, selanjutnya mensubtitusikan nilai variabel $x=0$ diperoleh hasil $y=12$, dan mensubtitusikan nilai variabel $y=0$ diperoleh hasil $x=6$. Subjek tidak memberikan jawaban mengenai daerah penyelesaian dari pertidaksamaan yang diketahui. Dari hasil wawancara diperoleh bahwa subjek belum memahami mengenai cara menentukan penyelesaian dari suatu pertidaksamaan. Oleh karena itu dapat disimpulkan bahwa subjek belum mampu mengembangkan konsep yang dipelajari, yaitu konsep mengenai daerah penyelesaian dari suatu pertidaksamaan.

\section{Minat Sedang : Jenis kelamin laki-laki}

Untuk indikator pertama yaitu mampu menjelaskan tentang apa yang telah dicapai, subjek SL mampu menjelaskan dengan singkat mengenai sistem persamaan linear dua variabel (SPLDV) dan sistem persamaan linear tiga variabel (SPLTV). Berikut jawaban subjek SL untuk indikator pertama.

Sistem Persamaan linear Dua variabel (SPLDV)
mempunyai 2 Variabel, mengunakan tanda sama
dengan $\Theta$, dan berpangkat satu.
sistem Persamaan linear Tiga variabel (SPLTV)
mempunyai 3 Variabel, menggunakan tanda sama
dengan E, dan berPangkat satu.
Gambar 9. Jawaban subjek SL untukindikator pertama

Dari jawaban di atas (Gambar 9) dapat dilihat bahwa subjek SL menjelaskan SPLDV sebagai sistem persamaan yang mempunyai dua variabel, menggunakan tanda sama dengan $(=)$, dan berpangkat satu. Sedangkan untuk SPLTV dijelaskan dengan sistem yang mempunyai tiga variabel, menggunakan tanda sama dengan $(=)$, dan berpangkat satu. Jawaban subjek perlu mendapatkan konfirmasi karena tidak dijelaskan apa yang disebut dengan berpangkat satu. Jawaban subjek pada saat wawancara mengenai SPLDV dan SPLTV hampir sama seperti apa yang dituliskannya pada saat tes. Hanya ditambahkan bahwa yang berpangkat satu adalah variabel-variabelnya. Oleh karena itu dapat disimpulkan bahwa subjek dapat menjelaskan tentang apa yang telah dicapainya, yaitu mengenai SPLDV dan SPLTV yang sebelumnya sudah ia pelajari pada pembelajaran. 
Untuk indikator kedua yaitu mampu menerapkan hubungan antara konsep dan prosedur, subjek SL kurang mampu menerapkan hubungan antara konsep SPLDV dengan prosedur untuk menentukan hasil dari SPLDV dengan cara eliminasi dan subtitusi karena terdapat kesalahan pada hasil. Berikut jawaban subjek SL untuk indikator kedua.

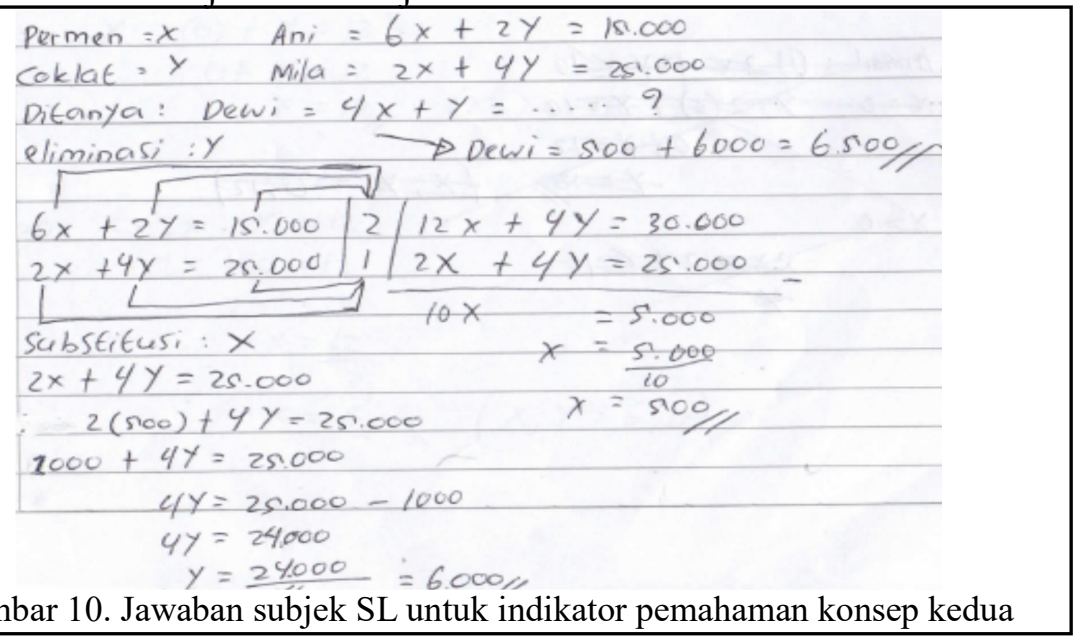

Dari jawaban di atas (Gambar 10) dapat dilihat bahwa subjek SL dapat menuliskan permodelan SPLDV dan persamaan yang ditanyakan dengan benar. Selanjutnya subjek SL melakukan prosedur untuk menentukan nilai $x$ dan $y$ dengan cara pertama-tama melakukan eliminasi variabel $y$ sehingga diperoleh nilai $x=500$. Kemudian nilai $x=500$ disubtitusikan ke persamaan kedua $(2 x+4 y=25000)$ sehingga diperoleh nilai $y=6000$. Setelah diperoleh nilai $x$ dan $y$, selanjutnya nilai-nilai tersebut disubtitusikan ke persamaan ketiga sehingga diperoleh hasil 6500. Prosedur yang dilakukan subjek SL untuk mencari nilai $x$ dan $y$ benar dan tidak ada kesalahan dalam perhitungan tetapi pada saat menentukan hasil dari persamaan yang ditanyakan subjek melakukan kesalahan, karena subjek tidak mengoperasikannya sesuai bentuk persamaan melainkan langsung menjumlahkan nilai $x$ dan nilai $y$ yang diperoleh sebelumnya sehingga hasil akhir yang diperoleh salah. Dari hasil wawancara, subjek SL dapat menjelaskan permodelan SPLDV dan prosedur perhitungan yang dilakukan dengan baik dan subjek menyadari kesalahan yang dilakukan setelah melihat kembali jawabannya. Walaupun terdapat kesalahan dalam jawaban subjek, dapat disimpulkan bahwa subjek mampu menerapkan hubungan antara konsep SPLDV dan prosedur penyelesaiannya dengan catatan subjek tidak cermat dalam melakukan proses perhitungan sehingga melakukan kesalahan.

Untuk indikator ketiga yaitu mampu memberikan contoh dan bukan contoh dari konsep yang sedang dipelajari, subjek SL dapat memberikan contoh dari SPLDV dan SPLTV dengan benar. Berikut jawaban subjek untuk indikator ketiga.

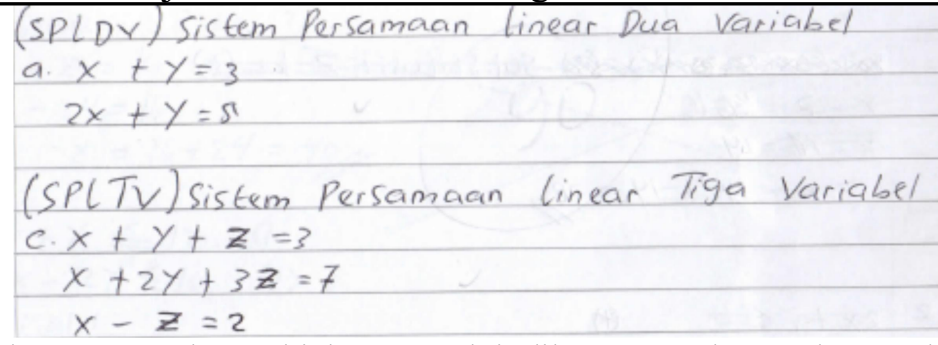

Gambar 11. Jawaban subjek SL untuk indikator pemahaman konsep ketiga

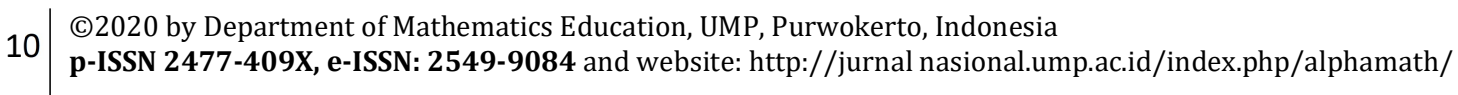




\section{AlphaMath \\ Journal of Mathematics Education, 6(1) May 2020}

Dari jawaban subjek di atas (Gambar 11) dapat dilihat bahwa subjek dapat menyebutkan contoh dari SPLDV dengan benar yaitu $\left\{\begin{array}{c}x+y=3 \\ 2 x+y=5\end{array}\right.$ dan dapat menyebutkan contoh dari

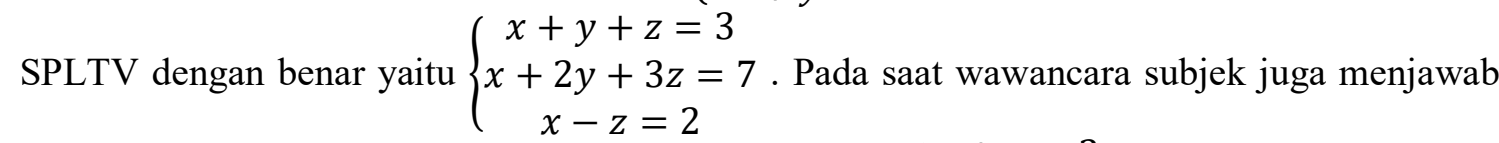
soal ini dengan jawaban yang sama. menurut subjek, $\left\{\begin{array}{c}x+y=3 \\ 2 x+y=5\end{array}\right.$ ini merupakan SPLDV karena terdiri dari dua variabel pada masing-masing persamaannya yaitu variabel $x$ dan $y$, sedangkan $\left\{\begin{array}{c}x+y+z=3 \\ x+2 y+3 z=7 \text { ini merupakan SPLTV karena terdiri dari tiga variabel pada } \\ x-z=2\end{array}\right.$ dua persamaan yaitu variabel $x, y$, dan $z$ walaupun untuk persamaan yang ketiga hanya ada dua variabel. Subjek hanya melihat pada persamaan satu dan dua saja dan tidak memperhatikan persamaan ketiga. Dari jawaban subjek dapat diketahui bahwa subjek dapat menyebutkan mana yang contoh dan bukan contoh dari SPLDV dan SPLTV. Oleh karena itu dapat disimpulkan subjek mampu memberikan contoh dan bukan contoh dari konsep SPLDV dan SPLTV.

Untuk indikator keempat yaitu mampu mengembangkan konsep yang telah dipelajari, subjek SL tidak mampu mengembangkan konsep pertidaksamaan dengan baik yaitu subjek tidak dapat menuliskan daerah penyelesaian dari suatu pertidaksamaan. Berikut jawaban subjek untuk indikator keempat.

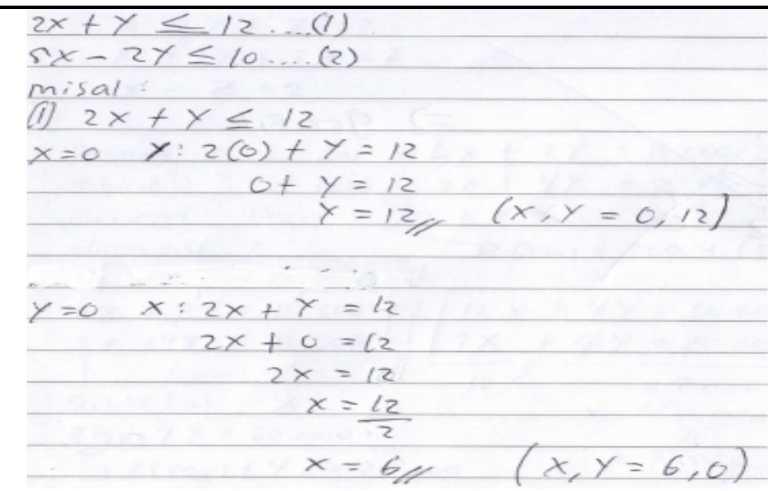

Gambar 12. Jawaban subjek SL untuk indikator pemahaman konsep keempat

Dapat dilihat pada jawaban subjek di atas (Gambar 12) bahwa subjek dapat menemukan titiktitik penyelesaian dari pertidaksamaan yang diketahui, yaitu dengan mensubtitusikan nilai $x=$ 0 pada pertidaksamaan $2 x+y \leq 12$ diperoleh nilai $y=12$, dan mensubtitusikan nilai $y=0$ pada pertidaksamaan yang sama diperoleh nilai $x=6$. Dari hasil tersebut diperoleh dua titik yaitu $(0,12)$ dan $(6,0)$, tetapi setelah diperoleh titik-titik penyelesaian, subjek tidak dapat menentukan daerah penyelesaian dari pertidaksamaan tersebut. Dari hasil wawancara diketahui bahwa subjek belum memahami mengenai daerah penyelesaian dan hanya memahami sebatas menentukan titik-titik penyelesaiannya saja. oleh karena itu dapat disimpulkan bahwa subjek belum dapat mengembangkan konsep pertidaksamaan yang dipelajari. 


\section{Minat Sedang : Jenis kelamin perempuan}

Untuk indikator pertama yaitu mampu menjelaskan tentang apa yang telah dicapai, subjek SP mampu menjelaskan mengenai SPLDV dan SPLTV berdasarkan ciri-ciri yang dimiliki. Berikut jawaban subjek untuk indikator pertama.

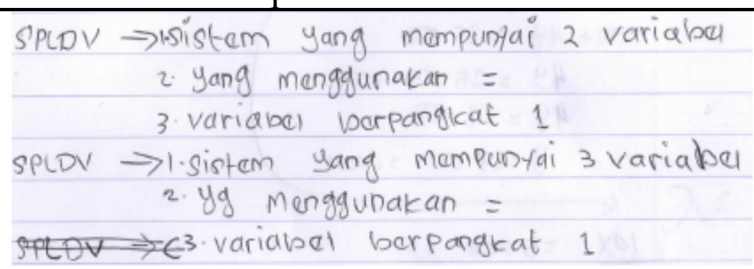

Gambar 13. Jawaban subjek SP untuk indikator pemahaman konsep pertama

Dari jawaban subjek SP di atas (Gambar 13) dapat dilihat bahwa subjek menjelaskan mengenai SPLDV dan SPLTV dengan menyebutkan ciri-cirinya, yaitu untuk SPLDV adalah sistem yang mempunyai dua variabel, yang mempunyai $(=)$, variabel berpangkat 1 . Sedangkan untuk SPLTV adalah sistem yang mempunyai 3 variabel, yang mempunyai $(=)$, variabel berpangkat 1 . Pada saat wawancara, subjek SP menjawab dengan cara yang sama yaitu menyebutkan ciri-ciri dari SPLDV dan SPLTV seperti pada jawaban tes. Oleh karena itu dapat disimpulkan bahwa subjek dapat menjelaskan tentang apa yang dicapai, yaitu mengenai SPLDV dan SPLTV.

Untuk indikator kedua yaitu mampu menerapkan hubungan antara konsep dan prosedur, subjek SP mampu menerapkan konsep SPLDV dengan prosedur untuk menentukan hasil dari SPLDV. Prosedur yang dilakukan subjek yaitu dengan cara eliminasi dan subtitusi. Berikut jawaban subjek untuk indikator kedua.

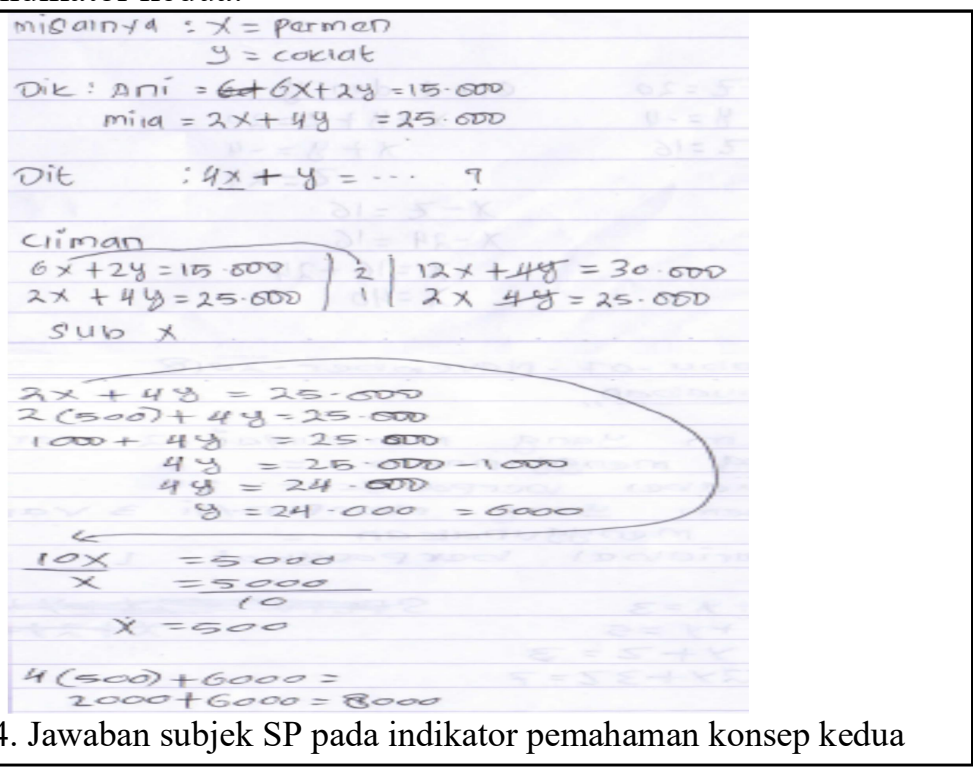

Dapat dilihat pada jawaban subjek di atas (Gambar 14) bahwa subjek mendefinisikan terlebih dahulu apa yang dimaksudkan dengan variabel $x$ dan $y$, yaitu variabel $x$ menunjukkan permen dan variabel $y$ menunjukkan cokelat. Selanjutnya subjek melakukan proses eliminasi variabel $y$ dan diperoleh nilai $x=500$. Kemudian subjek mensubtitusikan nilai $x=500$ ke persamaan dua $(2 x+4 y=25000)$ diperoleh nilai $y=6000$. Setelah itu subjek mensubtitusikan nilai $x=$ 500 dan nilai $y=6000$ pada persamaan yang ditanyakan dan diperoleh hasil 8000 . 
Untuk indikator ketiga yaitu mampu memberikan contoh dan bukan contoh dari konsep yang sedang dipelajari, subjek SP dapat memilih contoh dari SPLDV dan SPLTV dengan benar. Berikut jawaban subjek untuk indikator ketiga.

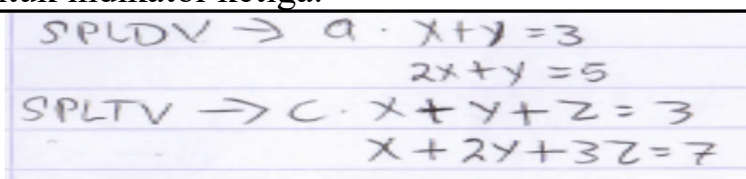

Gambar 15. Jawaban subjek SP pada indikator pemahaman konsep ketiga

Dari jawaban subjek (Gambar 15) dapat diketahui bahwa untuk menjawab contoh dari SPLDV subjek menuliskan opsi a yaitu $\left\{\begin{array}{c}x+y=3 \\ 2 x+y=5\end{array}\right.$. Untuk jawaban ini subjek memilih contoh dan menuliskannya dengan benar. Sedangkan untuk contoh dari SPLTV subjek menuliskan opsi c tetapi menuliskannya dengan $\left\{\begin{array}{c}x+y+z=3 \\ x+2 y+3 z=7\end{array}\right.$ seharusnya opsi c dituliskan dengan $\left\{\begin{array}{c}x+y+z=3 \\ x+2 y+3 z=7 . \text { Subjek memilih contoh dari SPLTV dengan benar tetapi } \\ x-z=2\end{array}\right.$ salah dalam menuliskannya. Ketika dicek pada kegiatan wawancara, subjek mengaku lupa menuliskannya karena mengerjakan dengan tergesa-gesa. Dapat disimpulkan bahwa subjek SP mampu memberikan contoh dan bukan contoh dari konsep yang sedang dipelajari, yaitu mengenai SPLDV dan SPLTV.

Untuk indikator keempat yaitu mampu mengembangkan konsep yang telah dipelajari, subjek SP tidak mampu mengembangkan konsep dari penyelesaian pertidaksamaan. Berikut jawaban subjek untuk indikator keempat.

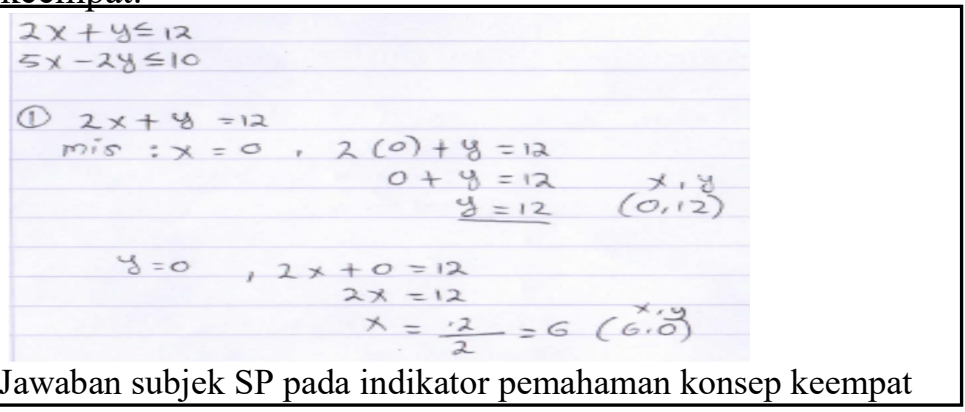

Dari jawaban subjek di atas (Gambar 16) dapat dilihat bahwa subjek tidak memahami mengenai konsep penyelesaian pertidaksamaan, karena subjek mengubah bentuk pertidaksamaan yang diketahui menjadi persamaan dan mencari penyelesaian dari persamaan tersebut. Diperoleh titik-titik penyelesaian $(0,12)$ dan $(6,0)$ dengan mensubtitusikan $x=0$ diperoleh nilai $y=12$ serta mensubtitusikan $y=0$ diperoleh nilai $x=6$. Dari jawaban subjek pada wawancara juga diketahui bahwa subjek belum memahami cara mencari penyelesaian dari suatu pertidaksamaan. Dapat disimpulkan bahwa subjek belum mampu mengembangkan konsep yang telah dipelajari yaitu mencari daerah penyelesaian dari suatu pertidaksamaan.

\section{Minat Rendah : Jenis kelamin laki-laki}

Untuk indikator pertama yaitu mampu menjelaskan tentang apa yang telah dicapai, subjek RL tidak mampu menjelaskan tentang apa yang telah dicapai dengan baik, yaitu menjelaskan mengenai SPLDV dan SPLTV. Berikut jawaban subjek untuk indikator pertama. 


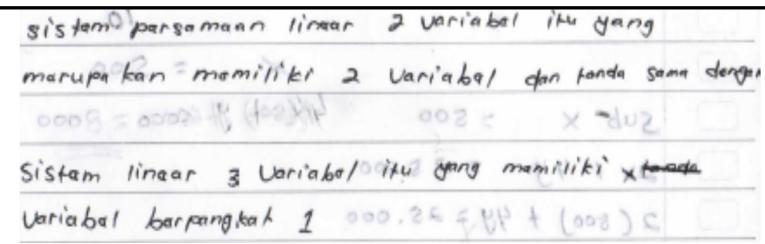

Gambar 17. Jawaban subjek RL pada indikator pemahaman konsep pertama

Dari jawaban subjek di atas (Gambar 17), dapat dilihat bahwa untuk SPLDV subjek RL menjelaskan sebagai yang merupakan memiliki 2 variabel dan tanda sama dengan. Sedangkan untuk SPLTV subjek RL menjelaskan sebagai yang memiliki variabel berpangkat 1. Jawaban subjek belum dapat menjelaskan dengan benar mengenai SPLDV dan SPLTV. Pada kegiatan wawancara juga subjek tidak mampu menjelaskan mengenai SPLDV dan SPLTV. Dapat disimpulkan bahwa subjek RL belum mampu menjelaskan tentang apa yang telah dicapai, yaitu menjelaskan mengenai SPLDV dan SPLTV.

Untuk indikator kedua yaitu mampu menerapkan hubungan antara konsep dan prosedur, subjek RL mampu menerapkan hubungan antara konsep penyelesaian SPLDV dengan prosedur yang digunakan berupa metode campuran antara eliminasi dan subtitusi. Berikut jawaban subjek untuk indikator kedua.

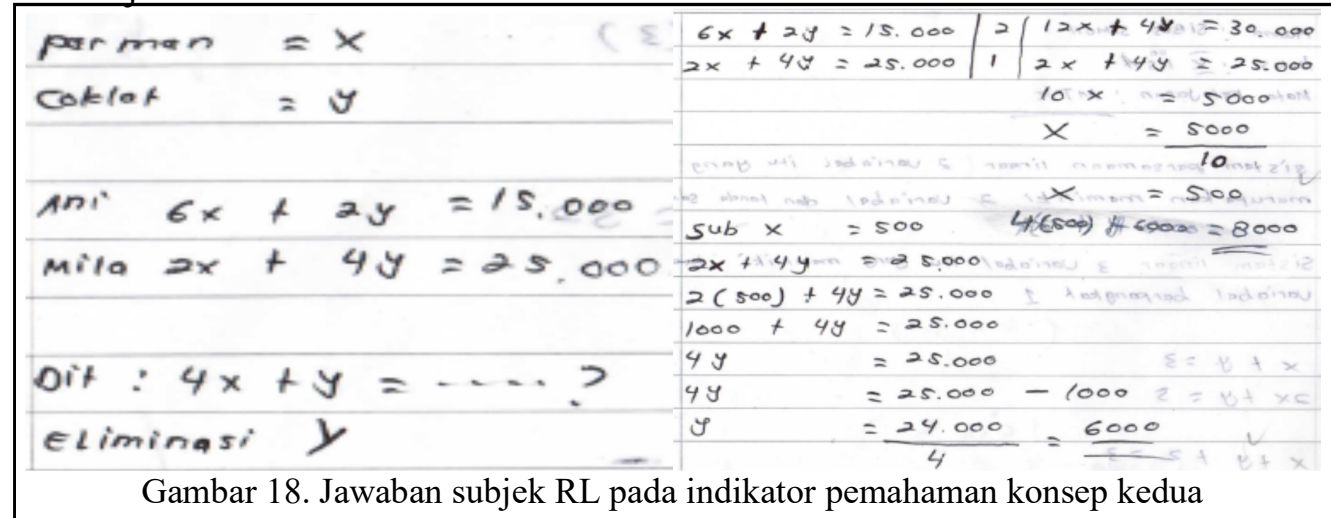

Dari jawaban subjek di atas (Gambar 18), dapat dilihat bahwa di awal penyelesaian subjek mendefinisikan permen dengan variabel $x$ dan cokelat dengan variabel $y$. Selanjutnya membuat persamaan untuk harga yang dibayar Ani yaitu $6 x+2 y=15000$ dan persamaan untuk harga yang dibayar Mila yaitu $2 x+4 y=25000$, dan ditanya hasil dari $4 x+y$. Prosedur yang digunakan untuk menentukan penyelesaian SPLDV yaitu dengan mengeliminasi variabel $y$ diperoleh nilai dari variabel $x=500$. Selanjutnya mensubtitusikan nilai $x=500$ pada persamaan dua yaitu $2 x+4 y=25000$ diperoleh nilai variabel $y=6000$. Kemudian nilai $x=500$ dan $y=6000$ disubtitusikan pada $4 x+y$ diperoleh hasil 8000 . Prosedur dan hasil perhitungan subjek RL benar hanya saja penulisannya tidak berurutan. Dari kegiatan wawancara, subjek RL menjelaskan prosedur yang dilakukan dengan baik dan benar. Dapat disimpulkan bahwa subjek RL mampu menerapkan hubungan antara konsep dan prosedur, yaitu antara konsep penyelesaian SPLDV dengan prosedur yang digunakan berupa metode eliminasi dan subtitusi.

Untuk indikator ketiga yaitu mampu memberikan contoh dan bukan contoh dari konsep yang sedang dipelajari, subjek RL dapat memberikan contoh dari SPLDV dan SPLTV dengan baik. Berikut jawaban subjek untuk indikator ketiga.

$14 \mid \begin{aligned} & \text { C2020 by Department of Mathematics Education, UMP, Purwokerto, Indonesia } \\ & \text { p-ISSN 2477-409X, e-ISSN: 2549-9084 and website: http://jurnal nasional.ump.ac.id/index.php/alphamath/ }\end{aligned}$ 


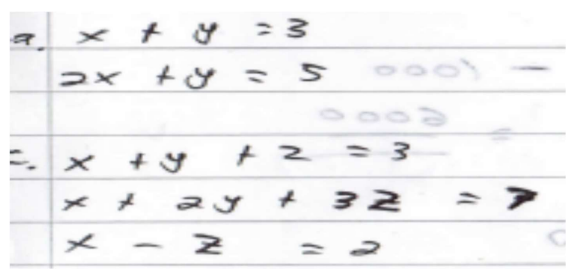

Gambar 19. Jawaban subjek RL pada indikator pemahaman konsep ketiga

Dari jawaban subjek RL di atas (Gambar 19), dapat dilihat bahwa untuk contoh SPLDV subjek menuliskan $\left\{\begin{array}{c}x+y=3 \\ 2 x+y=5\end{array}\right.$ dan contoh SPLTV subjek menuliskan $\left\{\begin{array}{c}x+y+z=3 \\ x+2 y+3 z=7 \\ x-z=2\end{array}\right.$ Subjek RL memilih dan menuliska contoh SPLDV dan SPLTV dengan benar. Dari jawaban pada kegiatan wawancara juga memberikan hasil yang sama. Dapat disimpulkan subjek RL mampu memberikan contoh dan bukan contoh dari konsep yang sedang dipelajari yaitu konsep SPLDV dan SPLTV.

Untuk indikator keempat yaitu mampu mengembangkan konsep yang telah dipelajari, subjek RL tidak mampu mengembangkan konsep mengenai penyelesaian suatu pertidaksamaan. Berikut jawaban subjek untuk indikator keempat.

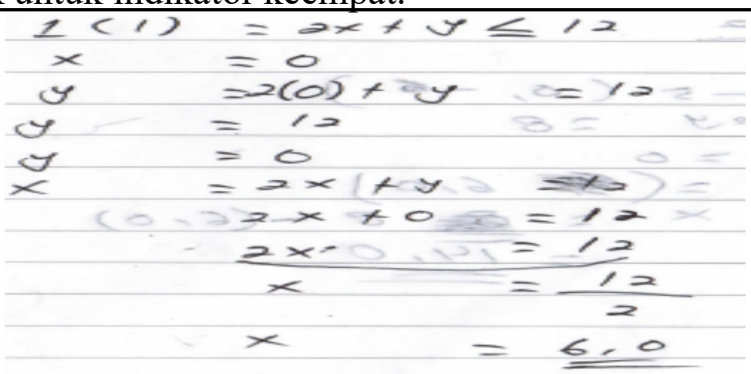

Gambar 20. Jawaban subjek RL pada indikator pemahaman konsep keempat

Dari jawaban subjek RL di atas (Gambar 20) dapat dilihat bahwa subjek mensubtitusikan nilai $x=0$ diperoleh $y=12$ dan mensubtitusikan nilai $y=0$ diperoleh nilai $x=6$. Jawaban yang ditulis subjek kurang dapat dipahami tetapi dapat dipastikan bahwa subjek tidak memahami cara mencari penyelesaian dari pertidaksamaan. Hal tersebut dikuatkan dengan jawaban subjek pada kegiatan wawancara yang menyatakan bahwa subjek tidak mengerti cara untuk menjawab soal ini. Dapat disimpulkan bahwa subjek RL belum mampu mengembangkan konsep yang telah dipelajari yaitu berkaitan dengan konsep penyelesaian suatu pertidaksamaan.

Minat Rendah : Jenis kelamin perempuan

Untuk indikator pertama yaitu mampu menjelaskan tentang apa yang telah dicapai, subjek RP tidak mampu menjelaskan mengenai SPLDV dan SPLTV dengan benar, khususnya penjelasan mengenai SPLTV. Berikut jawaban subjek untuk indikator pertama.

Sistem Parsamaan linear Dua Variabal adalah
2 Variabal
mengunakan tanda
Variabal berpangkatan (1)
Sistem Parsamaan linear Tiga variabal adalah
3 Variabol
mengunakan tanda =
Variabal borpangkatan (3)

Gambar 21. Jawaban subjek RP pada indikator pemahaman konsep pertama 
Dapat dilihat dari jawaban subjek di atas (Gambar 21), subjek menjelaskan SPLDV dengan 2 variabel, menggunakan tanda $=$, variabel berpangkatan 1 , tanpa menjelaskan bahwa SPLDV adala suatu sistem persamaan. Sedangkan untuk SPLTV subjek menjelaskan dengan 3 variabel, menggunakan tanda $=$, variabel berpangkatan 3. Penjelasan ini tentunya salah, karena tidak menjelaskan dengan suatu persamaan ditambah lagi variabel berpangkat 3. Dari hasil wawancara, subjek juga tidak dapat menjelaskan dengan benar mengenai SPLDV dan SPLTV. Dapat disimpulkan bahwa subjek tidak mampu menjelaskan tentang apa yang telah dicapai, yaitu mengenai SPLDV dan SPLTV.

Untuk indikator kedua yaitu mampu menerapkan hubungan antara konsep dan prosedur, subjek RP tidak mampu menerapkan prosedur dengan benar. Berikut jawaban subjek untuk indikator kedua.

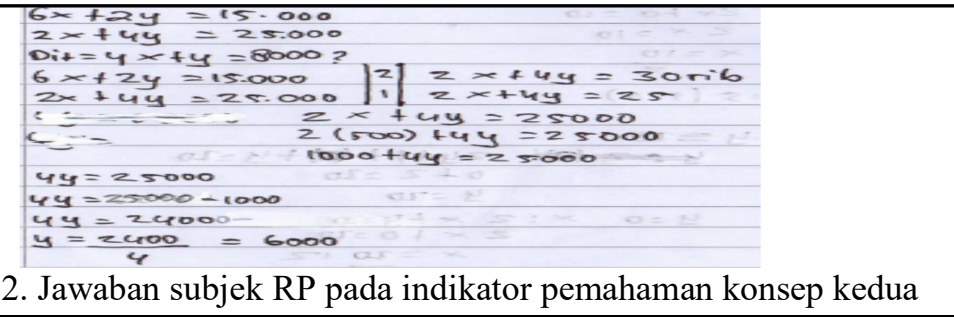

Gambar 22. Jawaban subjek RP pada indikator pemahaman konsep kedua

Dari jawaban subjek di atas (Gambar 22), dapat dilihat bahwa di awal penyelesaian subjek menuliskan persamaan yang diketahui yaitu $6 x+2 y=15000$ dan $2 x+4 y=25000$. Kemudian subjek RP menggunakan metode campuran untuk mencari penyelesaian dari SPLDV yaitu pertama mengeliminasi variabel $x$, tetapi prosesnya salah subjek mensubtitusi nilai $x=500$ pada proses eliminasi sehingga tidak diperoleh hasil yang benar. Seharusnya didapatkan hasil dari variabel $y$ tetapi subjek menghasilkan persamaan $1000+4 y=25000$ sampai $y=6000$ sebagai hasil dari metode eliminasi. Dari kegiatan wawancara, subjek tidak dapat membenarkan jawabannya yang salah. Dapat disimpulkan subjek tidak mampu menerapkan hubungan antara konsep dan prosedur, yaitu konsep penyelesaian SPLDV dengan prosedur eliminasi dan subtitusi.

Untuk indikator ketiga yaitu mampu memberikan contoh dan bukan contoh dari konsep yang sedang dipelajari, subjek RP tidak mampu memberikan contoh dari SPLTV. Berikut jawaban subjek untuk indikator ketiga.

$$
\text { a. } \begin{aligned}
& x+y=3 \\
2 x+y & =5
\end{aligned}
$$

Gambar 23. Jawaban subjek RP pada indikator pemahaman konsep ketiga

Dari jawaban subjek di atas (Gambar 23), dapat dilihat bahwa untuk SPLDV subjek menuliskan jawaban $\left\{\begin{array}{c}x+y=3 \\ 2 x+y=5\end{array}\right.$. Jawaban tersebut benar, subjek memilih contoh SPLDV dengan benar. Tetapi untuk contoh SPLTV subjek tidak dapat menyebutkan contoh yang merupakan SPLTV. Dari wawancara diketahui bahwa menurut subjek RP tidak ada yang merupakan contoh dari SPLTV dari opsi yang tersedia. Dari jawaban subjek dapat diketahui bahwa subjek RP belum memahami mengenai SPLTV. Dapat disimpulkan bahwa subjek tidak mampu memberikan contoh dan bukan contoh dari konsep yang sedang dipelajari, yaitu mengenai SPLDV dan SPLTV. 
Untuk indikator keempat yaitu mampu mengembangkan konsep yang telah dipelajari, subjek RP tidak dapat mengembangkan konsep mengenai penyelesaian dari suatu pertidaksamaan karena subjek tidak memberikan jawaban sama sekali untuk soal ini. Dari hasil wawancara diperoleh bahwa subjek tidak mengerti cara untuk mengerjakan soal ini, sehingga subjek RP memutuskan untuk tidak menjawab sama sekali. Dapat disimpulkan bahwa subjek tidak mampu mengembangkan konsep yang telah dipelajari, yaitu mengenai penyelesaian suatu pertidaksamaan.

\section{Simpulan}

Dari hasil analisis data tes pemahaman konsep dan kegiatan wawancara dapat disimpulkan bahwa untuk siswa berjenis kelamin laki-laki dan perempuan yang mempunyai minat belajar tinggi mempunyai kemampuan pemahaman konsep yang baik karena hanya tidak menguasai 1 indikator dari 4 indikator yang ada, yaitu siswa mampu menjelaskan tentang apa yang telah dicapai, mampu menerapkan hubungan antara konsep dan prosedur, mampu memberikan contoh dan bukan contoh dari konsep yang sedang dipelajari tetapi tidak mampu mengembangkan konsep yang telah dipelajari. Untuk siswa laki-laki dengan minat belajar sedang mempunyai kemampuan pemahaman konsep yang cukup baik karena menguasai 3 indikator dari 4 indikator, yaitu: siswa mampu menjelaskan tentang apa yang telah dicapai, siswa kurang mampu menerapkan hubungan antara konsep dan prosedur, mampu memberikan contoh dan bukan contoh dari konsep yang sedang dipelajari tetapi tidak mampu mengembangkan konsep yang telah dipelajari. Untuk siswa perempuan dengan minat belajar sedang mempunyai kemampuan pemahaman konsep yang baik karena tidak menguasai 1 indikator dari 4 indikator, yaitu: siswa mampu menjelaskan tentang apa yang telah dicapai, siswa mampu menerapkan hubungan antara konsep dan prosedur, mampu memberikan contoh dan bukan contoh dari konsep yang sedang dipelajari tetapi tidak mampu mengembangkan konsep yang telah dipelajari. Untuk siswa laki-laki dengan minat belajar rendah mempunyai kemampuan pemahaman konsep yang cukup karena menguasai 2 indikator dari 4 indikator, yaitu: siswa tidak mampu menjelaskan tentang apa yang telah dicapai, siswa mampu menerapkan hubungan antara konsep dan prosedur, mampu memberikan contoh dan bukan contoh dari konsep yang sedang dipelajari tetapi tidak mampu mengembangkan konsep yang telah dipelajari. Untuk siswa perempuan dengan minat belajar rendah mempunyai kemampuan pemahaman konsep yang sangat kurang karena belum menguasai keempat indikator yaitu: siswa tidak mampu menjelaskan tentang apa yang telah dicapai, siswa tidak mampu menerapkan hubungan antara konsep dan prosedur, tidak mampu memberikan contoh dan bukan contoh dari konsep yang sedang dipelajari dan tidak mampu mengembangkan konsep yang telah dipelajari.

Dari simpulan di atas diketahui bahwa untuk tingkat motivasi tinggi kemampuan pemahaman konsep siswa laki-laki dan perempuan hampir sama, sedangkan untuk tingkat motivasi sedang dan rendah kemampuan pemahaman konsep siswa laki-laki lebih baik dari perempuan.

Dapat disarankan sebaiknya pada pembelajaran matematika khususnya pada pokok bahasan Sistem Persamaan dan Pertidaksamaan Linear siswa yang mempunyai minat sedang dan rendah lebih diperhatikan agar siswa tersebut dapat memahami konsep mengenai materi yang diajarkan dengan baik. Selain itu dalam pembelajaran matematika, sebaiknya pembelajaran dapat meningkatkan minat belajar agar semua siswa lebih semangat untuk belajar dan siswa dapat memahami konsep matematika dengan baik. 


\section{Daftar Pustaka}

Anderson, L. W., \& Krathwohl, D. R. (2010). Kerangka Landasan untuk Pembelajaran, Pengajaran, dan Asesmen. Yogyakarta: Pustaka Pelajar.

Eggen, P., \& Kauchak, D. (2012). Strategi dan Model Pembelajaran: Mengajarkan Konten dan Keterampilan Berpikir. Jakarta: PT Indeks.

Friantini, R. N., \& Winata, R. (2019). Analisis Minat Belajar Pada Pembelajaran Matematika. JPMI: Jurnal Pendidikan Matematika Indonesia, 4(1), 6-11.

Ilyas, M., \& Basir, F. (2016). Analysis Of Student' S Conceptual Understanding Of Mathematics On Set At Class VII SMP Frater Palopo. In Proceedings of ICMSTEA 2016: International Conference on Mathematics, Science, Technology, Education, and their Applications, Makassar, Indonesia, 3rd - 4th October 2016 (pp. 96-102). Makassar. Retrieved from https://ojs.unm.ac.id/icmstea/article/view/2631

Komariyah, S., Afifah, D. S. N., \& Resbiantoro, G. (2018). Analisis Pemahaman Konsep Dalam Memecahkan Masalah Matematika Ditinjau Dari Minat Belajar Siswa. SOSIOHUMANIORA, 4(1), 1-8. Retrieved from https://jurnal.ustjogja.ac.id/index.php/sosio/article/view/1477

Lestari, K. E., \& Yudhanegara, M. R. (2017). Penelitian Pendidikan Matematika. Bandung: Refika Aditama.

Maulida, F. O., Mardiyana, M., \& Pramudya, I. (2017). Analisis Pemahaman Konsep Siswa Pada Materi Persamaan Lingkaran Ditinjau Dari Motivasi Belajar Siswa Kelas XII IPS 4 SMA Negeri 6 Surakarta Tahun Pelajaran 2016/2017. Jurnal Pendidikan Matematika Dan Matematika (JPMM) Solusi, 1(4), 26-45. Retrieved from https://jurnal.fkip.uns.ac.id/index.php/matematika/article/view/11603

Moleong, L. J. (2012). Metodologi Penelitian Kualitatif. Bandung: PT Remaja Rosdakarya.

Nasution. (2011). Berbagai Pendekatan dalam Proses Belajar \& Mengajar. Jakarta: PT Bumi Aksara.

Rifa'i, R., \& Dahliyah, C. (2018). Meningkatkan Pemahaman Konsep Matematis Siswa SMPN Satu Atap 8 Banjarsari Melalui Pendidikan Matematika Realistik Indonesia. BIORMATIKA Jurnal Ilmiah FKIP Universitas Subang, 4(01). Retrieved from http://ejournal.unsub.ac.id/index.php/FKIP/article/view/226

Santrock, J. W. (2007). Perkembangan Anak Jilid 2. Jakarta: Erlangga.

Sari, F. M., \& Harini, E. (2015). Hubungan Persepsi Siswa Terhadap Mata Pelajaran Matematika Minat Belajar dan Kemandirian Belajar dengan Hasil Belajar Matematika. UNION: Jurnal Pendidikan Matematika, 3(1), 61-68. Retrieved from https://jurnal.ustjogja.ac.id/index.php/union/article/view/280

Sudia, M. (2015). Profi 1 Metakognisi Siswa SMP dalam Memecahkan Masalah Terbuka Ditinjau dari Perbedaan Gender. Jurnal Pendidikan Dan Pembelajaran, 22(1), 17-24. Retrieved from http://ojs.uho.ac.id/index.php/JPM/article/view/2040

Sugiyono. (2010). Metode Penelitian Pendidikan: Pendekatan Kuantitatif, Kualitatif, dan $R \& D$. Bandung: Alfabeta. 